\title{
Living Memories
}

\section{Dubravka Stojanović* Being a Trainee Historian in Belgrade, 1989}

https://doi.org/10.1515/soeu-2021-0019

Abstract: The author reflects on the year 1989 when she was a newly hired trainee historian at the Institute for the History of the Serbian Labor Movement in Belgrade. The topic she was assigned in the Institute was the relationship of the Serbian Social Democratic Party to the war goals of Serbia 1912-1918. As her reading and writing progressed, by 1991 what the Serbian social democrats wrote about the Balkan Wars of 1912/13 began approaching her own political views. However, their antiwar positions at the beginning of the twentieth century sounded like a real feat compared to the virtually monolithic support for the war of 1991. This is how the author's first research left her with the bitter impression that history, the seeming magistra vitae, had really taught nobody anything given that Serbian society was falling into the same trap as some 70 years before.

Keywords: Balkan Wars of 1912/13, Kosovo, living memory, Serbia, Yugoslav wars of the 1990s

The year 1989 found me as a newly hired trainee historian at the Institute for the History of the Serbian Labor Movement. I suppose today getting a job at an institute with such a name sounds like a last-minute boarding on the Titanic, but I was very happy to get a job at this major historical institute after a long period of unemployment. Of course, no one could have predicted that the so-called Eastern Bloc would disappear that year, that any interest in the labor movement would evaporate, and that the institute's name would come to sound so passé overnight. Or rather, that it would be inappropriate in a new ideological environment. I think the subject of the interaction of historiographical paradigms and social reality is a good opening for this memoir-historical essay.

At the Institute, I was put in an office they called "kindergarten", because all the younger employees were there. Latinka Perovic (1985/1995; 1988; 1994; 2006; 2015), because she was being castigated, was also placed there with us. In

*Corresponding author: Dubravka Stojanović, Department of History, Faculty of Philosophy, University of Belgrade, Belgrade, Serbia. E-mail: dustojan@f.bg.ac.rs

¿ Open Access. ( 2021 Dubravka Stojanović, published by De Gruyter. (๕) BY-NC-ND This work is licensed under the Creative Commons Attribution-NonCommercial-NoDerivatives 4.0 International License. 
1969-1972, she had been secretary of the League of Communists of Serbia, part of the new generation that sought to reform Yugoslav socialism, primarily directing it towards a market economy. However, after crushing the Croatian Spring in 1971, which had analogous goals, Tito's regime decided to take "reciprocal measures" in Serbia, which meant that those individuals were removed that were identified as Serbian liberals, among whom Perović was one of the most prominent (Bešlin 2020). This was one of the most brutal political purges in socialist Yugoslavia, and it removed thousands of officials at all levels (Perović 1991). After being ousted from politics as part of the Serbian liberals in 1972, Latinka Perović got her Ph.D. and after several years of total isolation was "assigned" to the Institute. It turned out that my coming to that joint office had a decisive political effect on me, because this room brought together a team of female historians who would go on to play a crucial role in the modernization of Serbian historiography, as well as in the antiwar movement and the fight against nationalism. Later on, critics dubbed this group FSNH-the Female School of National History, in Serbian Ženska Škola Nacionale Istorije, ŽŠNI, which sounds pejorative-, a label we gratefully accepted, embracing this derogatory name as a badge of honor. In addition to Latinka Perović, this was the office of Branka Prpa (2018), Radmila Radić (1995; 1998; 2009), Marija Obradović (1995), and later Olga Manojlović (2014) and Radina Vučetić (2003; 2012; 2017), while we were also joined by historians such as Olivera Milosavljević (2002; 2006; 2010) from the Faculty of Philosophy and Olga Popović Obradović (1997; 2009; 2013) from the Law Faculty. I mention colleagues' most important works in this text.

At the Institute, which changed its name to Institute for the Recent History of Serbia, we used to stay until late in the evening, talking, first despairing about the events in Serbia, at the time of Milošević's “anti-bureaucratic revolution”, that is the populist meetings of 1988-1989 and the terror in Kosovo, and then about the wars in Yugoslavia (1991-1995). Another important figure was the Institute's director, Desanka Pešić (1983), a firm antinationalist. A good example of her attitude was what she did vis-à-vis a major rally held in downtown Belgrade on 28 February 1989. The rally, which drew tens of thousands of people (as many as a million according to the media), was a reaction to a miners' strike in Kosovo's Stari trg mine in Trepça, held in support of the ousted officials Azem Vllasi and Kaqusha Jashari (Ramet 2010). In the crisis, the Slovenian political leadership supported Kosovo's miners, provoking a revolt in Belgrade against both the situation in Kosovo and the Slovenian leadership (Repe 2019, 102; Ramšak 2021, in this issue). Scores of people poured into downtown Belgrade, many of them organized by companies that had been ordered to bring in their employees. This collective hysteria was not easy to resist, especially for people in leading positions. However, the director of the Institute for Recent History of Serbia-housed in Nemanjina street, which also houses several Serbian government ministries-had the courage and integrity to ignore the "instruction" and leave it to the employees to decide for themselves 
whether they would attend the rally or not. In those circumstances, this was the greatest degree of freedom possible.

Another equally important historical circle I entered that year was the one around professor Andrej Mitrović (1969; 1977; 1981; 1983; 1984; 1987; 1991; 2004; 2007) at the Department of History of the Faculty of Philosophy. A scholar of German history who wrote the best book on interwar Europe in Serbian historiography, Mitrović (1974; 1979) unmistakably recognized the populist elements in the Milošević regime. He wrote and spoke forcefully about where Serbia and Yugoslavia were heading, reminding us of the situation in the 1930s (Mitrović 1998). His fervent position was also a result of the fact that his wife, our colleague, historian Ljubinka Trgovčević (1986; 1992; 2003), worked in Ivan Stambolić's government. Stambolić was President of the Presidency of Serbia in 1986-1987, a reformist politician, but was forced to resign by Slobodan Milošević in autumn 1987. In August 2000, he was assassinated by Special Operation Unit officers. In 1987, he was replaced by Slobodan Milošević at the Eighth Session of the League of Communists of Serbia (Pavlović, Jović, and Petrović 2007), the beginning of the downfall. Thanks to these events, the Mitrović-Trgovčević family knew first-hand what kind of regime was consolidating before our eyes. They accurately read the meaning of the "anti-bureaucratic revolution", the rallies of support, the abuse of the Kosovo myth, the suppressing and abolishing of Kosovo's autonomy, and the use of violence in the province. It was then that I first heard Ljubinka Trgovčević say that the Kosovo drama was being constructed to destroy Yugoslavia. Better than most critics of the regime, both as insiders and as historians, she, as did her husband, accurately interpreted the events and spoke out warnings that it was all leading to disaster. After the round table meetings Andrej Mitrović held every Tuesday at the Faculty of Philosophy, we would go to a café or to their place, where we would discuss all through the night the dramatic political events and everything that came upon us (on Andrej Mitrović cf. Godišnjak 2013).

It is important to understand the mood in Belgrade at the time, the euphoria and the heightened emotions that dominated (Čolović 1993). Mass movements, the "happening of the people" as it was called, big words, promises, and expectations clouded minds (Mimica and Vučetić 2008). Such unanimity and exclusivity was difficult to defy, especially because monolithism was no longer a government dictate, but an authentic single-mindedness (Stojanović 2000). Compared to socialism, when being a dissident was chic, now it meant being very lonely and sticking out. Nationalism had taken over the masses, any talk against it meant being accused of treason, those holding a different opinion were said to have definitely been bribed with "foreign money". Homogenization was almost total, the nation was turning into a monolith. There was no room for different views. Apart from the circle around Latinka, Andrej, and Ljubinka, the only other historians "in this team" were the medievalist Sima Ćirković (1964; 2004; 2008) and the byzantologist Ivan Đurić (1985; 1998; 2009), who publicly spoke and wrote extremely critically in those years. 
Unfortunately, many historians then joined the government's propaganda machinery (Milosavljević 2000). Before our eyes, history began to be revised. Yugoslavia first needed to be dismembered as an idea, it needed to be portrayed as a prison of the Serbian people (Dragović-Soso 2002; Milosavljević 2000). What was needed was a self-victimizing narrative, a paranoid picture of the past, in which Serbia is surrounded by enemies and forced to defend itself (Stojanović 1994). Kosovo was ideal for that (Čolović 2016). Because of its mythical place in collective historical memory, the growing vocal demands for making the autonomous province a Republic of Kosovo, and the increasing displacement of Serbs (Bogosavljević 1994), it was the perfect foundation for raising nationalist sentiments.

The Kosovo problem opened a wider question of the Yugoslav federation (Popović, Petovar, and Janča 1990). Namely, the federal Yugoslavia consisted of six republics (Đorđević 1975), and the Republic of Serbia harboured two autonomous provinces-Kosovo and Vojvodina (Aksić 1967). This was supposed to give greater autonomy and more self-government to the national minorities living there, but over time it became a central controversial constitutional issue. This was especially the case after the 1974 Constitution was adopted (Dimitrijević 2000). It further federalized the country and gave the provinces a series of powers, including the power of veto on Belgrade's decisions. In many circles, especially intellectual ones in Belgrade (Đurić 1971, 230-3), the Constitution was seen as going against Serbian interests. So, from the very beginning, part of the nationallyoriented opposition rallied around the question of changing Serbia's constitutional position within Yugoslavia (Popović 2011). The question on everyone's mind was why of all the republics only Serbia was divided into provinces, and this intensified tensions within Serbia, but also in the Yugoslav federation. Since Tito's death in May 1980 and the economic crisis of the early 1980s, there were those who argued for a new constitutional solution that would give greater rights to Serbs, the most numerous nation in Yugoslavia (Memorandum of the Serbian Academy of Sciences and Arts 1986). This strengthened a paranoid historical consciousness, and there were claims that Yugoslavia was a mistake for which the Serbs paid the heaviest price. In that marketplace of words, Kosovo was priced the highest, or as Matija Bećković (1989, n.p.) put it: "Kosovo is the most expensive Serbian word.” A sense of threat and fear was developing, and the masses of Serbs came to Belgrade to "rallies of truth", with "truth" portrayed as something long-hidden that was finally revealed. This mix was able to produce intense sentiments.

Although the Yugoslav drama began to unfold in 1987 with the taking on of power of Slobodan Milošević, the year 1989, a watershed in Europe, accelerated the turn of events in Yugoslavia, although quite independently of the collapse of the so-called Eastern Bloc's regimes (Čolović 2009). The Yugoslav crisis already had its 
own isolated dynamic, which was taking the worst possible turn. By the beginning of the year, on 10 January, the Montenegrin leadership was ousted and a group of younger functionaries, Milošević's proxies led by Milo Đukanović, rose to power (Prpa 2004, 406-9). On 20 February, Albanian miners from the Stari trg mine went on strike over the removal of Kosovo's political leaders Azem Vllasi and Kaqusha Jashari and the appointment of a new leadership close to Milošević. Protests began spreading in Kosovo, including schools, universities, and transportation workers. A week after the demonstrations broke out, a support rally for the Albanian miners was held in Ljubljana, at the Cankar Hall, where Milan Kučan, then President of the League of Communists of Slovenia, said that the Stari trg miners' strike was a defense of Yugoslavia as envisioned by the Antifascist Council for the National Liberation of Yugoslavia (Antifašističko veće narodnog oslobođenja Jugoslavije, AVNOJ) (Repe 2019, 106). This in turn triggered the largest demonstrations in Serbia up to that point, which drew hundreds of thousands of people in cities across the country. A huge crowd gathered before the Assembly of the Socialist Federal Republic of Yugoslavia and demanded that Milošević arrest Azem Vllasi, which he soon did, also arresting a number of Kosovar functionaries who were accused of organizing the miners' strike.

In March 1989, Vojvodina and Kosovo adopted amendments to the Serbian Constitution, which significantly restricted their autonomy (Popović 2011). This set off a new eruption of discontent in Kosovo, leading to the introduction of a state of emergency, movement restrictions, curfews, school closures, and the introduction of obligatory work duty. The day when the amendments were adopted in the Serbian Assembly, 28 March, was declared a national holiday, even though while this Assembly session was taking place, lives were being lost in the largest unrest ever recorded in Kosovo. Apart from that, preparations were underway for a major rally in Gazimestan on 28 June 1989, which marked the sixth centenary of the Battle of Kosovo (Čolović 2016). Not long before that, on 9 June, a year-long transference of the remains of Prince Lazar, killed in the Battle in Kosovo, took place across different parts of Yugoslavia, which was the first public delineation of the imagined borders of a state "in which all Serbs would live", a common saying of the time. It was another symbolic gesture that clearly showed that Kosovo was only a prelude to a far wider Yugoslav war drama, which was confirmed only a few days after Gazimestan, at the Battle of Kosovo commemoration in Dalmatinsko Kosovo, Croatia, where demands for greater rights to Serbs in Croatia were issued.

On the opposite end of Yugoslavia, in Slovenia, things were heating up. Late September saw the passing of the amendments to the Slovenian Constitution, which became the legal framework for this republic's independence (Repe 2019). 
Relations with Belgrade were further damaged with the banning of the planned "Serbian Rally of Truth" in Ljubljana, scheduled for 1 December (to commemorate the declaration of the Kingdom of Serbs, Croats, and Slovenes in 1918), which was supposed to enlighten the Slovenians on the position of Serbs in Kosovo. After the rally was banned, Belgrade was quick to react-it declared a boycott of Slovenian goods, which, as many subsequently argued, was one of the crucial moments in the breakup of Yugoslavia (Jović 1995). Along with the crisis deepening, other currents were developing. Prime minister Ante Marković's economic reform agenda was adopted, which will be remembered as the golden age of Yugoslav citizens' living standard. Political parties were founded, paving the way for multipartyism, and the first elections held in 1990, which might have looked like things were moving in the direction taken by the rest of Eastern Europe. But instead of European integration and transition, Yugoslavia turned to war (Baker 2015).

The hostility soon shifted to Croatia and Croats, from Kosovo to the mass graves of the Independent State of Croatia (Nezavisna Država Hrvatska, NDH) of the Second World War (1941-1945), which was best expressed by Bishop Anatasije Jeftić (1985) in the title of his book From Kosovo to Jadovno, Jadovno being the location of a concentration camp in the NDH, established in May 1941 close to the town of Gospic. The question of the Serbian position in Kosovo spilled over onto the entire Yugoslav territory, raising the issue of rearranging relations between the Yugoslav nations. Ljubinka Trgovčević's claims were thus being confirmed, that Kosovo was being used for dismantling Yugoslavia and going to war with Croatia. As historians, we watched, virtually as in a live broadcast, how our discipline was abused, how it was being exploited for dangerous propaganda, how facts were distorted, how everything was suddenly possible. Facts were twisted, some were "forgotten", others overemphasized, interpretations were changing, those that did not fit the desired image of the past were left out. And this desired image of the past was one of continuity of conflict between the Yugoslav nations, which portrayed their history as a series of conflicts from the time before the Balkans were settled in the seventh century. This constructed a historical context that justified the contemporary conflicts, creating the illusion that the nations of Yugoslavia could only live in conflict, as their natural state. All periods of cooperation, partnership, and closeness were erased, so that the present could be placed in a suitable context that would remove all responsibility, because "such is our history" (Todorova 2004, 7). It was clear that what awaited us was not only the fight against nationalism, the breakup of Yugoslavia, and the war, but also a fight for our discipline. 
With this, something unusual began happening in my career. After a while, the subjects I dealt with as a historian began coinciding with social reality, so my works increasingly looked more like forecasts and less like analyses of the past. Namely, I got the job at the Institute in the first place because a colleague who had previously worked there died, and the system at the time meant that I inherited his subject as well. So there was no choice. As said, the topic I was assigned was the Serbian Social Democratic Party (Srpska socijaldemokratska partija, SSDP), which I had made a point of ignoring in school as a form of protest against the communist regime, because the way the party was presented then was pure propaganda. Fortunately, my mentor, professor Andrej Mitrović, succeeded in giving a meaning to this topic which caught my interest, at least to some degree, so the topic of my master's thesis became the relation of the SSDP to the war goals of Serbia in the Balkan Wars and the First World War between 1912 and 1918 (Stojanović 1994b).

After extensive research, I was ceremonially supposed to begin writing my master's thesis on 27 June 1991 (I should mention that in the Yugoslav/Serbian system, the master's thesis is what is the Ph.D. dissertation elsewhere). After hours of looking at a blank piece of paper (note: paper, no screens back then!), the phone rang. It was my grandfather who said that it looked like war had broken out in Slovenia. I turned on the TV to watch a live broadcast of what was going on, but I also put away that piece of paper, deciding that it would be immoral to write while war was going on in my country. I soon realized that the war was going to last a while and that it would be better to get back to my work.

As my reading and writing progressed, by 1991 what the Serbian social democrats wrote about the Balkan Wars of 1912/13 began approaching my own political views. Their antiwar positions and the fact that they were among the few parliamentarians in Europe to vote against joining the First World War sounded like a real feat compared to the virtually monolithic support for war in 1991 Serbia. Their articles were also topical, stating that any war in the Balkans would be a trigger for new wars, because irredentist minorities would remain in the ethnically mixed territory and endeavor to change the borders and bring about new war (Socijaldemokratija i nacionalno pitanje, Radničke novine, 19 Oct 1912). In 1912, they rallied against the idea of a Greater Serbia, warning:

The illusion of Greater Serbia cost us dearly. This illusion prevented us from developing economically and culturally, it sacrificed our education to army barracks, it provoked chauvinist anger in our masses, it soothed us with false hopes that cost us too much. (Jedno priznanje, Radničke novine, 14 Sep 1912).

In particular, in addition to party founder Dimitrije Tucovićs's (1914) book Serbia and Albania, they regularly wrote about Serbian-Albanian relations in their paper 
Radničke novine. They rebelled against the Serbian army's attempt to conquer northern Albania and attain a sea exit for Serbia (1912), against the siege of the Albanian town of Shkodra (1913), and especially against the introduction of a military-police regime in Kosovo and Macedonia, when they became part of Serbia in 1913. They wrote in their paper: "Denying the new citizens their political freedoms is a crime, a violent act that leaves them with a bad impression of us and lays the groundwork for dangerous precedents and incidents in the country" (Sloboda ili reakcija, Radničke novine, 29 Aug 1913). They constantly repeated how "only a regime of freedom and respect for national and religious sentiments of this diverse people could remove, as much as possible, the constant threat of war that we face" (Naša nužnost, Radničke novine, 2 Nov 1913).

This was a new game with historical contexts and historiography. My unwanted master's thesis topic attained a whole new and unexpected meaning. From my initial aversion towards it as a mainstream propagandist subject, it became for me not only an explanation and answer to the present, but also a kind of safety valve in a situation of hopelessness that became prevalent with the growing Yugoslav crisis and preparations for war.

This was largely, but in a different manner, also the case with my Ph.D. thesis (which in the Serbian system is what elsewhere is known as "habilitation"). Its subject was the "European Democratic Models among the Serbian Political and Intellectual Elite 1903-1914”, and it covered the introduction of democratic models to Serbia during the period commonly known as "the golden age of Serbian democracy" (Stojanović 2003, 2nd ed. 2019). My work and the events "on the ground" were again related. I was about to start writing my thesis when NATO began their bombing of the Federal Republic of Yugoslavia, caused by the war in Kosovo and the Serbian rejection of the plan that the international community proposed at the negotiations in the Castle of Rambouillet outside Paris. The subject of my thesis was not as much related to the national question or the Kosovo question as was my master's thesis. But there was one important subsection about the form of government in the "new regions", the territories which Serbia took over after the Balkan Wars of 1912/13, including Kosovo, part of Sandžak, and Vardar Macedonia. In 1913, the National Assembly debated whether it should extend the Serbian Constitution to those regions, with all the broad democratic rights enjoyed by Serbian citizens, or introduce a separate police-military regime. It was one of the most interesting debates led both in the Assembly and in public, because it raised some of the most important questions of democracy and equality. The ruling People's Radical Party (Narodna radikalna stranka, NRS) argued for introducing a state of emergency, claiming that "our citizens from the new regions are lagging behind us in development" 
(Stenografske beleške Narodne skupštine, 1 Mar 1912, 1142) and that introducing modern institutions, especially broad suffrage, would undermine political stability. Their opponents were the otherwise ideologically very diverse Progressive Party (Srpska napredna stranka, SNS) and the Independent Radical Party (Samostalna radikalna stranka, SRS). They fought hard for several months calling for the equality of citizens before the law as a fundamental democratic idea, arguing that the citizens of the "new regions" should also be granted all the rights. The Independent Radicals were particularly harsh, writing in their party daily:

The fusionists [the People's Radical Party, D.S.] declared half of the Kingdom of Serbia [Kosovo, Sandžak and Macedonia] their eyalet. Through their minister of the interior, they declared that it was not Serbia, and in those regions which they do not consider Serbian, they instituted a regime of their own design. (Fuzionaški pašaluk, Odjek, 30 Nov 1913).

They considered that granting all rights and freedoms to "new citizens" was a fundamental principle of the new world and that giving up on those principles would turn back politics to the premodern era. The social democrats once again were the most explicit: "Depriving new citizens of political freedoms constitutes a crime, an act of violence that leaves them with a bad impression of us and sows the seeds for dangerous precedents and incidents in the country" (Sloboda ili reakcija, Radničke novine, 29 Aug 1913). So, through the texts I analyzed, everyday reality was again intertwined with historical precedents.

Later in my career, my work increasingly dealt with the subject of culture of remembrance (Stojanović 2010), in which again the question of Kosovo and the Battle of Kosovo became the central traumas essential for the Serbian nation's selfvictimization and homogenization (Čolović 2016). This is interesting because, in fact, I never wanted the Kosovo question to be my central point of interest, and subjects like social democracy, the transfer of democratic ideals or the representation of the past in history textbooks seemed to be far removed from it. But it clearly kept asserting itself. As for my historiographical work, this made sense, especially if I consider Lucien Febvre's definition of history as the science of the present. That is to say, understanding the present and the key issues of today is what drives us to learn about the past. In that sense, it is only natural that Kosovo has become my topic, regardless of my methodological and thematic starting point.

At the same time, this political issue helped shape my private life from 1981 onwards, from when the Kosovo question first exploded in Yugoslavia. That year I began studying history at the Faculty of Philosophy in Belgrade. It was then, already, that the Yugoslav crisis divided friends and families. Political conflicts 
spilled over into our living rooms and completely reshaped our lives. I replaced almost all my friends from that period, because most of them allied with the Serbian nationalist project. But at the same time, I met entirely new circles of people, especially in the 1990s with the antiwar movement, the Belgrade Circle, the Center for Antiwar Action, and the Civil Alliance of Serbia party (Građanski savez Srbije). This is how my beginnings as a trainee historian collided with contemporary political questions and dilemmas. To this day, none of it has changed.

\section{References}

Aksić, S. 1967. Položaj autonomnih pokrajina u ustavnom sistemu SSFRJ. Belgrade: Naučna knjiga. Baker, C. 2015. The Yugoslav Wars of the 1990s. London: Red Globe Press.

Bećković, M. 1989. Kosovo najskuplja srpska reč. Valjevo: Glas crkve.

Bešlin, M. 2020. Ideja moderne Srbije u socijalističkoj Jugoslaviji. Belgrade: Akademska knjiga. Bogosavljević, S. 1994. Statistička slika srpsko-albanskih odnosa. Sukob ili dijalog. Subotica: Otvoreni univerzitet.

Ćirković, S. 1964. Istorija srednjevekovne bosanske države. Belgrade: Srpska književna zadruga. Ćirković S. 2004. Srbi među evropskim narodima. Belgrade: Equilibrium.

Ćirković S. 2008. The Serbs. New Jersey: Wiley-Blackwell.

Čolović, I. 1993. Bordel ratnika. Folklor, politika, rat. Belgrade: XX vek, Krug - Medijska knjižara.

Čolović, I. 2016. Smrt na Kosovu polju. Istorija Kosovskog mita. Belgrade: XX vek, Krug - Medijska knjižara.

Čolović, I., ed. 2009. Zid je mrtav, živeli zidovi! Pad Berlinskog zida i raspad Jugoslavije. Belgrade: XX vek, Krug - Medijska knjižara.

Dimitrijević, V. 2000. "Sukobi oko Ustava iz 1974." In The Road to War in Serbia. Trauma and Catharsis, edited by N. Popov, 399-425. Budapest et al.: Central European University Press.

Dragović-Soso, J. 2002. Saviours of the Nation: Serbian Intellectual Opposition and the Revival of Nationalism. London: McGill - Queen's University Press.

Đorđević, J. 1975. Društveno politički sistem SFRJ. Belgrade: Radnička stampa.

Đurić, I. 1998. Istorija - pribežište ili putokaz? Sarajevo: Svjetlost.

Đurić, I. 1985. Sumrak Vizantije. Vreme Jovana VIII Paleologa. Belgrade: Narodna knjiga.

Đurić, I. 2009. Vlast, opozicija, alternative. Belgrade: Helsinški odbor za ljudska prava u Srbiji.

Đurić, M. 1971. “Smišljene smutnje.” Anali Pravnog fakulteta 3: 230-3.

Đorđević, J. 1975. Društveno politički sistem SFRJ. Belgrade: Radnička stampa.

"Fuzionaški pašaluk." Odjek. 30 November 1913.

Godišnjak za društvenu istoriju 2013. 20: 2.

“Jedno priznanje." Radničke novine. 14 September 1912.

Jeftić, A. 1985. Od Kosova do Jadovna: Putni zapisi jeromonaha Atansasija Jevtića. Belgrade: Autor Bgd.

Jović, B. 1995. Poslednji dani SFRJ: Izvodi iz dnevnika iz perioda 15.V. 1989. do 8. VII. 1995.

Belgrade: Politika Bgd.

Manojlović Pintar, O. 2014. Arheologija sećanja. Spomenici i identiteti u Srbiji 1918-1989.

Belgrade: Cigoja, Udruženje za društvenu istoriju. 
"Memorandum of the Serbian Academy of Sciences and Arts, 1986." In Eastern European Nationalism in the Twentieth Century, edited by P.F. Sugar, 332-46. Washington/DC: The American University Press.

Milosavljević, 0. 2000. "The Abuse of the Authority of Science." In The Road to War in Serbia. Trauma and Catharsis, edited by N. Popov, 50-81. Budapest et al.: Central European University Press.

Milosavljević, 0. 2000. "Yugoslavia as a Mistake." In The Road to War in Serbia. Trauma and Catharsis, edited by N. Popov, 274-303. Budapest et al.: Central European University Press.

Milosavljević, 0. 2002. U tradiciji nacionalizma. Stereotipi srpskih intelektualaca 20. veka o "nama" $i$ "drugima". Belgrade: Helsinški odbor za ljudska prava u Srbiji.

Milosavljević, 0. 2006. Potisnuta istina: Kolaboracija u Srbiji 1941-1944. Belgrade: Helsinški odbor za ljudska prava u Srbiji.

Milosavljević, 0. 2010. Savremenici fašizma. Percepcije fašizma u beogradskoj javnosti 19331941. Belgrade: Helsinški odbor za ljudska prava u Srbiji.

Mimica, A., and R. Vučetić. 2008. Vreme kada je narod govorio. Odjeci i reagovanje u Politici, 1988-1991. Belgrade: Filozofski fakultet, Institut za sociološka istraživanja.

Mitrović, A. 1969. Jugoslavija na Konferenciji mira 1919-1920. Belgrade: Zavod za izdavanje udžbenika Socijalističke Republike Srbije.

Mitrović, A. 1974. Vreme netrpeljivih. Politička istorija velikih država Evrope 1919-1939. Belgrade: Cid.

Mitrović, A. 1977. Istorijsko u Čarobnom bregu. Pokušaj interdisciplinarnog ogleda. Belgrade: Kolarčev narodni univerzitet.

Mitrović, A. 1979. Fašizam i nacizam. Belgrade: Politika Beograd.

Mitrović, A. 1981. Prodor na Balkan. Srbija u planovima Austro-Ugarske i Nemačke 1908-1918. Belgrade: Zavod za Udžbenike.

Mitrović, A. 1983. Angažovano i lepo. Umetnost u razdoblju svetskih ratova 1914-1945. Belgrade: Narodna knjiga.

Mitrović, A. 1984. Srbija u Prvom svetskom ratu. Belgrade: Službeni glasnik.

Mitrović, A. 1987. Ustaničke borbe u Srbiji 1916-1918. Belgrade: Zavod za udžbenike.

Mitrović, A. 1991. Razpravljanja s Klio o istoriji, istorijskoj svesti i istoriografij. Sarajevo: Svjetlost.

Mitrović, A. 1998. Vreme destruktivnih. Čačak: Čačanski glas.

Mitrović, A. 2004. Strane banke u Srbiji. Politika, progress, evropski okvir. Belgrade: Stubovi kulture.

Mitrović, A. 2007. Serbia's Great War. London: Purdue University Press.

“Naša nužnost.” Radničke novine. 2 November 1913.

Obradović, M. 1995. Narodna demokratija u Jugoslaviji 1945-1952. Belgrade: Institut za noviju istoriju Srbije.

Pavlović, M., D. Jović, and V. Petrović, eds. 2007. Slobodan Milošević - put ka vlasti. Osma sednica CK SKS - uzroci, tok i posledice. Srbija 20 godina kasnije. Belgrade: Institut za savremenu istoriju.

Perović, L. 1985-1995. Srpski socijalisti 19. veka. Prilog istoriji socijalističke misli, vols. 1-3. Belgrade: Službeni list SRJ.

Perović, L. and L. Subotin 1988. Planirana revolucija. Ruski blankizam i jakobinizam. Belgrade et al.: Beogradski izdavačko-grafički zavod.

Perović, L. 1991. Zatvaranje kruga. Ishod rascepa 1971-1972. Sarajevo: Sarajevo University Press.

Perović, L. 1994. Srpsko-ruske revolucionarne veze. Prilozi za istoriju narodnjaštva u Srbiji. Belgrade: Službeni List SRJ. 
Perović, L. 2006. Između anarhije i autokratije. Srpsko društvo na prelazima vekova (XIX - XXI).

Belgrade: Helsinski odbor za ljudska prava u Srbiji Beograd.

Perović, L. 2015. Dominantna i neželjena elita. Beleške o intelektualnoj i političkoj eliti u Srbiji (XXXXI vek). Belgrade: Dan Graf.

Pešić, D. 1983. Jugoslovenski komunisti i nacionalno pitanje 1919-1935. Belgrade: Rad.

Popović Obradović, O. 1997. Parlamentarizam u Srbiji 1903-1914. Belgrade: Službeni list SRJ. /

Popović Obradović, O. 2013. The Parliamentary System in Serbia 1903-1914. Belgrade:

Helsinski odbor za ljudska prava u Srbiji Beograd.

Popović Obradović, O. 2009. Kakva ili kolika država: Ogledi o političkoj i društvenoj istoriji Srbije XIX-XXI veka. Belgrade: Helsinski odbor za ljudska prava u Srbiji Beograd.

Popović S., T. Petovar, and D. Janča. 1990. Kosovski čvor: drešiti ili seći. Belgrade: Shronos.

Popović, S. 2011. One gorke suze posle. Belgrade: Peščanik.

Prpa, B., ed. 2004. Moderna srpska država 1804-2004. Hronologija. Belgrade: Istorijski Arhiv Beograda.

Prpa, B. 2018. Srpski intelektualci i Jugoslavija. Belgrade: Clio.

Radić, R. 1995. Verom protiv vere. Država i verske zajednice u Srbiji 1945-1953. Belgrade: INIS.

Radić, R. 1998. Hilandar u državnoj politici Kraljevine Srbije i Jugoslavije 1896-1970. Belgrade: Službeni list SRJ.

Radić, R. 2009. Narodna verovanja, religija i spiritizam u srpskom društvu 19. i u prvoj polovini 20. veka. Belgrade: Institut za noviju istoriju Srbije.

Ramet, S. P. 2010. Central and Southeast European Politics since 1989. Cambridge: Cambridge Core.

Repe, B. 2019. Milan Kučan. Prvi predsjednik Slovenije. Sarajevo: Udruženje za modernu historiju. "Sloboda ili reakcija." Radničke novine. 29 August 1913.

"Socijaldemokratija i nacionalno pitanje." Radničke novine. 19 October 1912.

"Stenografske beleške Narodne skupštine," 1 March 1912. Belgrade: Narodna skupština.

Stojanović, D. 1994a. "History Textbooks Mirror their Time." In Warfare, Patriotism, Patriarchy: the Analysis of Elementary School Textbooks, edited by V. Pešić and R. Rosandić, 81-111.

Belgrade: Centre for Antiwar Action.

Stojanović, D. 1994b. Iskušavanje načela. Srpska socijaldemokratska stranka i ratni program Srbije 1912-1918. Belgrade: Timit Book.

Stojanović, D. 2000. "Traumatic Circle of Serbian Opposition.” In The Road to War in Serbia. Trauma and Catharsis, edited by N. Popov, 449-79. Budapest et al.: Central European University Press.

Stojanović, D. 2003., 2nd ed. 2019. Srbija i demokratija. Ogled o "zlatnom dobu demokratije" 1903 -1914. Belgrade: Udruženje za društvenu istoriju.

Stojanović, D. 2010. Ulje na vodi. Ogledi iz istorije sadašnjosti Srbije. Belgrade: Peščanik. Todorova, M., ed. 2004. Balkan Identities. Nation and Memory. London: NYU Press.

Trgovčević, L. 1986. Naučnici Srbije i stvaranje jugoslovenske države 1914-1920. Belgrade: Narodna knijga.

Trgovčević, L. 1992. Istorija Srpske književne zadruge. Belgrade: Srpska književna zadruga.

Trgovčević, L. 2003. Planirana elita: o studentima iz Srbije na evropskim univerzitetima u 19. veku. Belgrade: Istorijski Institut.

Tucović, D. 1914. Srbija i Albanija. Jedan prilog kritici zavojevačke politike srpske buržoazije. Belgrade: Socijalističke knjižare.

Vučetić, R. 2003. Evropa na Kalemegdanu. Belgrade: Službeni glasnik. 
Vučetić, R. 2012. Koka-kola socijalizam. Belgrade: Službeni glasnik.

Vučetić, R. 2017. Monopol na istinu. Belgrade: Clio.

\section{Bionote}

Dubravka Stojanović is a professor at the History Department, Faculty of Philosophy, Belgrade University. She teaches global contemporary history. She has published nine books dealing with the transfer of democratic models to Serbia, social history, the urban history of Belgrade, and history textbooks analyses. 